\title{
Front Matter: Volume 9018
}

, "Front Matter: Volume 9018," Proc. SPIE 9018, Measuring, Modeling, and Reproducing Material Appearance, 901801 (11 March 2014); doi:

$10.1117 / 12.2053728$

SPIE Event: IS\&T/SPIE Electronic Imaging, 2014, San Francisco, California, United SPIE. States 


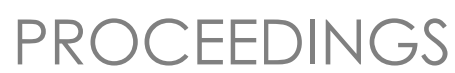

IS\&T / SPIE

Electronic

Imaging

SCIENCE AND TECHNOLOGY

\section{Measuring, Modeling, and Reproducing Material Appearance}

Maria V. Ortiz Segovia

Philipp Urban

Jan P. Allebach

Editors

3-4 February 2014

San Francisco, California, United States

Sponsored and Published by

IS\&T-The Society for Imaging Science and Technology

SPIE 
The papers included in this volume were part of the technical conference cited on the cover and title page. Papers were selected and subject to review by the editors and conference program committee. Some conference presentations may not be available for publication. The papers published in these proceedings reflect the work and thoughts of the authors and are published herein as submitted. The publishers are not responsible for the validity of the information or for any outcomes resulting from reliance thereon.

Please use the following format to cite material from this book:

Author(s), "Title of Paper," in Measuring, Modeling, and Reproducing Material Appearance, edited by Maria V. Ortiz Segovia, Philipp Urban, Jan P. Allebach, Proceedings of SPIE-IS\&T Electronic Imaging, SPIE Vol. 9018, Article CID Number (2014)

ISSN: 0277-786X

ISBN: 9780819499356

Copublished by

SPIE

P.O. Box 10, Bellingham, Washington 98227-0010 USA

Telephone +1 3606763290 (Pacific Time) · Fax +1 3606471445

SPIE.org

and

IS\&T-The Society for Imaging Science and Technology

7003 Kilworth Lane, Springfield, Virginia, 22151 USA

Telephone +1 7036429090 (Eastern Time) · Fax +1 7036429094

imaging.org

Copyright (C) 2014, Society of Photo-Optical Instrumentation Engineers and The Society for Imaging Science and Technology.

Copying of material in this book for internal or personal use, or for the internal or personal use of specific clients, beyond the fair use provisions granted by the U.S. Copyright Law is authorized by the publishers subject to payment of copying fees. The Transactional Reporting Service base fee for this volume is $\$ 18.00$ per article (or portion thereof), which should be paid directly to the Copyright Clearance Center (CCC), 222 Rosewood Drive, Danvers, MA 01923. Payment may also be made electronically through CCC Online at copyright.com. Other copying for republication, resale, advertising or promotion, or any form of systematic or multiple reproduction of any material in this book is prohibited except with permission in writing from the publisher. The CCC fee code is 0277-786X/14/\$18.00.

Printed in the United States of America.

Paper Numbering: Proceedings of SPIE follow an e-First publication model, with papers published first online and then in print and on CD-ROM. Papers are published as they are submitted and meet publication criteria. A unique, consistent, permanent citation identifier (CID) number is assigned to each article at the time of the first publication. Utilization of CIDs allows articles to be fully citable as soon as they are published online, and connects the same identifier to all online, print, and electronic versions of the publication. SPIE uses a six-digit CID article numbering system in which:

- The first four digits correspond to the SPIE volume number.

- The last two digits indicate publication order within the volume using a Base 36 numbering

system employing both numerals and letters. These two-number sets start with 00, 01, 02, 03, 04, $05,06,07,08,09,0 A, 0 B \ldots$. OZ, followed by 10-1Z, 20-2Z, etc.

The CID Number appears on each page of the manuscript. The complete citation is used on the first page, and an abbreviated version on subsequent pages. Numbers in the index correspond to the last two digits of the six-digit CID Number. 


\section{Contents}

vii Conference Committee
ix Introduction

KEYNOTE PRESENTATION: JOINT SESSION WITH CONFERENCES 9014 AND 9018

901802 Perceiving, measuring, and modeling materials (Keynote Paper) [9018-1]

C. W. Tyler, Smith-Kettlewell Eye Research Institute (United States)

\section{MEASURING}

901803 Rapid determination of the photometric bidirectional scatter distribution function by use of a near-field goniophotometer [9018-2]

F. B. Leloup, Katholieke Univ. Leuven (Belgium); W. De Ketelaere, ETAP nv (Belgium);

J. Audenaert, P. Hanselaer, Katholieke Univ. Leuven (Belgium)

901804 Multidimensional reflectometry for industry (xD-Reflect): an European research project [9018-3]

A. Höpe, Physikalisch-Technische Bundesanstalt (Germany); A. Koo, Measurement Standards Lab. (New Zealand); F. M. Verdu, Univ. de Alicante (Spain); F. B. Leloup, Katholieke Univ. Leuven (Belgium); G. Obein, Conservatoire National des Arts et Metiers (France); G. Wübbeler, Physikalisch-Technische Bundesanstalt (Germany); J. Campos, Consejo Superior de Investigaciones Científicas (Spain); P. lacomussi, Istituto Nazionale di Ricerca Metrologica (Italy); P. Jaanson, Mittatekniikan Keskus (Finland); S. Källberg, SP Sveriges Tekniska Forskningsinstitut AB (Sweden); M. Šmíd, Cesky Metrologicky Institut Brno (Czech Republic)

901805 Evaluation of the shape of the specular peak for high glossy surfaces (Invited Paper) [9018-4]

G. Obein, S. Ouarets, G. Ged, Conservatoire National des Arts et Metiers (France)

901806 Analysis of aberrations and pixel information in goniometric multispectral imaging [9018-5] J. Klein, G. Schmücking, RWTH Aachen Univ. (Germany)

901807 A line scan camera based stereo method for high resolution 3D image reconstruction [9018-6]

P. Zhang, T. Takeda, J. A. Toque, Y. Murayama, A. Ide-Ektessabi, Kyoto Univ. (Japan)

901808 An investigation into the micro surface of artworks using alternative lighting techniques [9018-7]

F. Tisato, Univ. degli Studi di Ferrara (Italy); C. Parraman, Univ. of the West of England (United Kingdom) 
901809 Topographical scanning and reproduction of near-planar surfaces of paintings [9018-8] W. S. Elkhuizen, T. Zaman, Technische Univ. Delft (Netherlands); W. Verhofstad, Océ Technologies B.V. (Netherlands); P. P. Jonker, J. Dik, Technische Univ. Delft (Netherlands); J. M. P. Geraedts, Technische Univ. Delft (Netherlands) and Océ Technologies B.V. (Netherlands)

$90180 \mathrm{~A}$ State of the art of 3D scanning systems and inspection of textile surfaces [9018-9] M. Montilla, S. A. Orjuela-Vargas, Univ. Antonio Nariño (Colombia); W. Philips, Univ. Gent (Belgium)

\section{MATERIAL COLORS: JOINT SESSION WITH CONFERENCES 9015 AND 9018}

9018 OC Estimating Neugebauer primaries for multi-channel spectral printing modeling [9018-11] R. Slavuj, L. G. Coppel, Gjøvik Univ. College (Norway); M. Olen, Univ. of the West of England (United Kingdom); J. Y. Hardeberg, Gjøvik Univ. College (Norway)

9018 OD An interactive tool for gamut masking [9018-12]

Y. Song, C. Lau, S. Süsstrunk, Ecole Polytechnique Fédérale de Lausanne (Switzerland)

9018 OE A new connection space for low-dimensional spectral color management [9018-13] S. Le Moan, Technische Univ. Darmstadt (Germany); P. Urban, Fraunhofer Institute for Computer Graphics Research IGD (Germany)

9018 OF Extension of Murray-Davies tone reproduction model by adding edge effect of halftone dots [9018-14]

G. M. A. Rahaman, O. Norberg, P. Edström, Mid Sweden Univ. (Sweden)

PERCEPTION AND APPEARANCE OF MATERIALS: TEXTURE, LUMINANCE, AND NOISE: JOINT SESSION WITH CONFERENCES 9014 AND 9018

9018 OG Mathematical limitations when choosing psychophysical methods: geometric versus linear grey scales [9018-15]

N. Dekker, Akzo Nobel Coating B.V. (Netherlands); M. Lucassen, LUCASSEN Colour Research (Netherlands); E. Kirchner, Akzo Nobel Coating B.V. (Netherlands); P. Urban, Fraunhofer Institute for Computer Graphics Research IGD (Germany); R. Huertas, Univ. de Granada (Spain)

$9018 \mathrm{OH}$ The visual appearance and surface texture of materials according to the old masters [9018-16]

C. Parraman, Univ. of the West of England (United Kingdom)

9018 ol On pictures and stuff: image quality and material appearance [9018-17]

J. A. Ferwerda, Rochester Institute of Technology (United States)

MODELING

9018 0J Modeling cloth at micro resolution (Invited Paper) [9018-18]

K. Bala, Cornell Univ. (United States)

iv 
9018 OK Towards a better understanding of the color shift of effect coatings by densely sampled spectral BRDF measurement [9018-19]

A. Ferrero, B. Bernad, J. Campos, Consejo Superior de Investigaciones Científicas (Spain); F. M. Martínez-Verdú, E. Perales, Univ. de Alicante (Spain); I. van der Lans, E. Kirchner, Akzo Nobel Coating B.V. (Netherlands)

$9018 \mathrm{OL}$ Lateral light propagation and angular variation of the reflectance of paper [9018-20]

L. G. Coppel, Gjøvik Univ. College (Norway)

9018 OM Printing gloss effects in a 2.5D system [9018-21]

T. Baar, Océ Print Logic Technologies (France) and Institut Mines-Télécom, Télécom ParisTech, CNRS LTCI Paris (France); S. Samadzadegan, Technische Univ. Darmstadt (Germany); H. Brettel, Institut Mines-Télécom, Télécom ParisTech, CNRS LTCI Paris (France); P. Urban, Fraunhofer Institute for Computer Graphics Research IGD (Germany); M. V. Ortiz Segovia, Océ Print Logic Technologies (France)

\section{REPRODUCTION}

9018 ON Image ghosting reduction in lenticular relief prints [9018-23]

T. Baar, Océ Print Logic Technologies (France) and Institut Mines-Télécom, Télécom ParisTech, CNRS LTCI Paris (France); M. Shahpaski, Ecole Polytechnique Fédérale de Lausanne (Swaziland); M. V. Ortiz Segovia, Océ Print Logic Technologies (France)

901800 Continuous tone printing in silicone from CNC milled matrices [9018-24]

S. Hoskins, P. McCallion, Univ. of the West of England (United Kingdom)

9018 OP Characterization of relief printing [9018-25]

X. Liu, Purdue Univ. (United States); L. Chen, Rochester Institute of Technology (United States); M.-V. Ortiz-Segovia, Océ Print Logic Technologies (France); J. Ferwerda, Rochester Institute of Technology (United States); J. Allebach, Purdue Univ. (United States)

$90180 Q \quad$ Method for visualization and presentation of priceless old prints based on precise 3D scan [9018-26]

E. Bunsch, Wilanow Palace Museum (Poland); R. Sitnik, Warsaw Univ. of Technology (Poland)

Author Index 
SPIE-IS\&T/ Vol. $9018901801-6$

Downloaded From: https://www.spiedigitallibrary.org/conference-proceedings-of-spie on 26 Apr 2023 Terms of Use: https://www.spiedigitallibrary.org/terms-of-use 


\section{Conference Committee}

Symposium Chair

Sergio R. Goma, Qualcomm Inc. (United States)

Symposium Cochair

Sheila S. Hemami, Northeastern University (United States)

Conference Chairs

Maria V. Ortiz Segovia, Océ Print Logic Technologies (France)

Philipp Urban, Fraunhofer Institute for Computer Graphics Research IGD (Germany)

Jan P. Allebach, Purdue University (United States)

Conference Program Committee

Susan P. Farnand, Rochester Institute of Technology (United States)

James A. Ferwerda, Rochester Institute of Technology (United States)

Jon Yngve Hardeberg, Gjøvik University College (Norway)

Andreas Höpe, Physikalisch-Technische Bundesanstalt (Germany)

E. J. J. Kirchner, Akzo Nobel Coating B.V. (Netherlands)

Susanne Klein, Hewlett-Packard Laboratories (United Kingdom)

Carinna E. Parraman, University of the West of England

(United Kingdom)

Sabine Süsstrunk, Ecole Polytechnique Fédérale de Lausanne

(Switzerland)

Françoise Viénot, Muséum National d'Histoire Naturelle (France)

Session Chairs

Keynote Presentation: Joint Session with Conferences 9014 and 9018

Jan P. Allebach, Purdue University (United States)

$1 \quad$ Measuring

Maria V. Ortiz Segovia, Océ Print Logic Technologies (France)

Philipp Urban, Fraunhofer Institute for Computer Graphics Research IGD (Germany)

2 Material Colors: Joint Session with Conferences 9015 and 9018

Maria V. Ortiz Segovia, Océ Print Logic Technologies (France)

Jon Yngve Hardeberg, Gjøvik University College (Norway) 
3 Perception and Appearance of Materials: Texture, Luminance, and Noise: Joint Session with Conferences 9014 and 9018

Philipp Urban, Fraunhofer Institute for Computer Graphics Research IGD (Germany)

Bernice E. Rogowitz, Visual Perspectives Consulting (United States)

$4 \quad$ Modeling

Sabine Süsstrunk, Ecole Polytechnique Fédérale de Lausanne (Switzerland)

5 Reproduction

Carinna E. Parraman, University of the West of England (United Kingdom) 


\section{Introduction}

The rapid and continuous development of rendering devices such as displays and printers offers interesting challenges related to how materials are understood. Over the years, researchers from different disciplines have studied the interaction of incident light with the texture and surface geometry of a given object, as well as the optical properties of distinct materials. Thanks to those efforts, we have been able to render with high accuracy 2.5D and 3D objects and scenes. But given the day-to-day technological improvements of materials and devices along with the advances in the areas of visual and tactile perception, modeling how light interacts with materials, and techniques for measuring material properties, the field of material appearance is in constant evolution. This conference offers the possibility to share research results and establish new collaborations among academic and industrial researchers from these related fields.

The main topics encountered on the papers of this document correspond to any of the following categories:

Methods for measuring material properties: measurement of Bidirectional Reflectance Distribution Functions (BRDF), Bidirectional Texture Functions (BTF) and Bidirectional Surface Scattering Reflectance Distribution Function (BSSRDF); estimation of material difference perception; evaluation of metallic coatings/inks; measurement of glossiness; estimation of texture perception; data acquisition methods for different types of materials.

Models for distinct characteristics of materials: modeling of Bidirectional Reflectance Distribution Functions (BRDF), Bidirectional Texture Functions (BTF) and Bidirectional Surface Scattering Reflectance Distribution Function (BSSRDF); modeling material difference perception; appearance modeling of glossiness and texture; modeling of varnish and special effects inks; softproofing methods for $2.5 \mathrm{D}$ and $3 \mathrm{D}$ printing.

Material reproduction aspects: quality evaluation of 2.5D and 3D soft- and hardcopy reproductions (display and printing); estimation of effects of environmental aspects in material perception (lighting, observers' position, printing media); estimation of sensory input (visual, touch, audio) effect in material perception; evaluation of aesthetic aspects of 2.5D and 3D soft- and hard-copy reproductions (display and printing); saliency of 2.5D and 3D soft- and hard-copy reproductions (display and printing); imaging and perception of metallic and effect coatings/inks; saliency, quality, and aesthetics in appearance reproduction; spectral reproduction.

Maria V. Ortiz Segovia Philipp Urban Jan P. Allebach 
SPIE-IS\&T/ Vol. $9018901801-10$

Downloaded From: https://www.spiedigitallibrary.org/conference-proceedings-of-spie on 26 Apr 2023 Terms of Use: https://www.spiedigitallibrary.org/terms-of-use 